\title{
Use of Vanoxerine Consta In Cocaine Addiction: A Case Report
}

\author{
Sümeyye DEMIRBAY ${ }^{1}$, Zehra ALGAN², Neslihan CANSEL ${ }^{1}$, Hatice Birgül CUMURCU1
}

\begin{abstract}
Cocaine abuse is a serious health problem in many regions of the world, however, there are no proven effective drugs for the treatment of cocaine addiction. In this presentation, diagnosis, treatment and monitoring processes of a 33-yearold male patient, using vanoxerine constants in the treatment of cocaine addiction, will be shared. In the story taken, it was learned that the patient started to use cocaine 7-8 months ago.After the patient was applied a intramuscular treatment, 394,2 $\mathrm{mg}$ of vanoxerine consta, three times with three months intervals, it was observed that withdrawal symptoms and cocaine desire decreased.In addition, one-year follow-up of the patient revealed that his well-being continued and the urine substance panels were negative.Vanoxerin limits cocaine-induced increase in extracellular dopamine by competing with cocaine in the dopamine transporter region.Cocaine abuse is a harmful habit spreading to the world, causing socioeconomic problems.
\end{abstract}

Keywords: Addiction, Cocaine, Vanoxerine

\section{Kokain Bağımlılığında Vanoxerine Consta Kullanımı: Bir Olgu Sunumu}

Özet: Kokain istismarı, dünyanın pek çok bölgesinde ciddi bir sağlık sorunudur, ancak kokain bağımlılığının tedavisi için kanıtlanmış etkili ilaçlar bulunmamaktadır. Bu sunumda kokain bağımlılığı tedavisinde vanoxerine constanın kullanıldığı 33 yaşında erkek hastaolguyla ilgili tanı, tedavi ve izleme süreçleri paylaşılacaktır. Alınan öyküde hastanın yaklaşık 7-8 ay öncekokain kullanmaya başladığı öğrenildi. Hastaya vanoxerine consta 394,2 mg intramüsküler tedavisi üçer ay arayla üç kez uygulandıktan sonra yoksunluk belirtilerinin ve kokain isteğinin azaldığı gözlendi. Ayrıca hastanın bir yıllık takibinde iyilik halinin devam ettiği ve idrarda madde panellerinin negatif çıktığı görüldü.Vanoxerin dopamin taşıyıcı bölgesinde kokainle yarışarak hücre dışı dopaminde kokainin neden olduğu artışı sınırlandırmaktadır. Kokain istismarı, dünyaya yayılan, sosyoekonomik problemlere neden olan zararlı bir alışkanlıktır.

Anahtar Kelimeler: Bağımlılık, Kokain, Vanoxerin

\footnotetext{
${ }^{1}$ Ast. Department of Adult Mental Health and Diseases, Inonu University

${ }^{2}$ Ast. Department of Child and Adolescent Mental Health and Diseases, İnönü University

${ }^{1}$ Uzm. Dr. Department of Adult Mental Health and Diseases, Inonu University

${ }^{1}$ Prof. Dr. Department of Adult Mental Health and Diseases, Inonu University

Address of correspondence/Yazışma adresi: Ast. Sümeyye Demirbay, Department of Adult Mental Health and Diseases, Inonu University, Malatya, Turkey E-mail: smdemirbay@gmail.com

Date of Received/Geliş Tarihi: 27.10.2019, Date of Revision/Düzeltme Tarihi: 02.11.2019, Date of Acceptance/Kabul Tarihi: 06.11.2019

Citing/ Referans Gösterimi: Demirbay, S., Algan, Z., Cansel, N., Cumurcu, H.B. (2019). Use of Vanoxerıne Consta In Cocaine Addiction: A Case Report. Kıbrls Türk Psikiyatri ve Psikoloji Dergisi, 1(Özel Sayl.1): 69-71 doi:10.35365/ctjpp.19.special1.20
} 


\section{Introduction}

Cocaine (benzoylmethylecgonine) is a tropane crystal alkaloid obtained from the leaves of the coca plant.Serotonin (5-HT), dopamine (DA) and noradrenaline (NA) in the cerebral cortex and prefrontal cortex are reuptake inhibitors (Castells, Casas, Pérez- Mañá, Roncero, Vidal, \& Capella, 2010; Kalivas, Duffy, 1990; Luoh, Kuo, Chan, Pan, 1994). It has been known that the basic functional and addictive effects of cocaine occur through dopaminergic neurotransmission systems, especially in mesostriatal regions (Koob, Nestler, 1997; Holman, 1994; Volkow, Wang, Fowler, Logan, Franceschi, Maynard, \& Swanson, 2002). Cocaine increases alertness, energy and motor activity with a strong stimulating effect on the nervous system. It evokes a sense of euphoria, increases self-confidence and improves sexual ability (Volkow, Wang, Fowler, Logan, Gatley \& Wong, 1999). Because of such effects, the improper use of cocaine has become inevitable.

Cocaine abuse is a serious health problem in many regions of the world, however, there are no proven effective drugs for the treatment of cocaine addiction.

In this presentation, the diagnosis, treatment and monitoring processes related to the case of vanoxerine consta used in the treatment of cocaine addiction will be shared.

\section{Case}

A 33-year-old male patient applied to our polyclinic for the first time in July 2018 , by considering that cocaine use had caused him material and moral harm.In the story taken, it was learned that the patient started to use cocaine in a friend environment about 7-8 months ago and then also used different forms of cocaine (crack, stone).After using cocaine for the last month, he said that he began to think that people were watching him and he heard voices commanding his ears. The patient said that at that time he had even had to sell his car, under the influence of his lack and desire.It was learned that the patient had been hospitalized in order to quit substance use in a private clinic, but he had spent 2 days in the first and 5 days in the second, and had voluntarily left.The patient said that he had recently used up to 5 grams of cocaine per day. After the patient was applied a intramuscular treatment, 394,2 mg of vanoxerine consta, three times with three months intervals, it was observed that withdrawal symptoms and cocaine desire decreased. In addition, one-year follow-up of the patient revealed that his well-being continued and the urine substance panels were negative. The most recent interview revealed that the patient felt very well and had no cocaine desire and withdrawal symptoms.

\section{Discussion}

In animal studies, Vanoxerine has been shown to reduce the symptoms of cocaine and to reduce the search behavior of cocaine-containing foods in rhesus monkeys (Glowa, Wojnicki, Matecka, Rice \& Rothman 1995). Vanoxerin limits cocaine-induced increase in extracellular dopamine by competing with cocaine in the dopamine transporter region. (Rothman, Mele, Reid, Akunne, Greig \& Thurkauf 1991). Vanoxerine (GBR12909 ) is a powerful, highly selective, dopamine carrier antagonist, originally developed for the treatment of Parkinson's disease (Andersen, 1989). Also It has been studied in healthy subjects and patients suffering from major depression (Fensbo, Montgomery, Andersen, Hallstrom, Schonbeck, Zwaan, M0oler Nielsen, Olafsson, Ingwersen, \& Skrumsager, 1990). Behavioral characterization has shown that vanoxerine possesses no stimulant activity but exhibits high potency in 'antidepressant' models. Thus, it may be beneficial in the treatment of depressions (Andersen, 1989).

In another preclinical study for use in cocaine addiction, vanoxerine has been reported to be a potent hERG inhibitor (Matsumoto, Khrestian, Ryu, Lacerda, Brown \& Waldo, 2010).

\section{Conclusion}

Cocaine abuse is a costly and health-damaging habit that spreads worldwide and causes disease, crime, domestic violence and low productivity (Hanzlick \& Gowitt 1991). Cocaine addiction causes many psychotic symptoms that are most commonly associated with cocaine consumption, which can impair a person's quality of life; reference thoughts and delusions, thought of oppression and auditory / verbal hallucinations. Therefore, we think that treatment of cocaine addiction will provide important contributions to the literature.

\section{References}

Andersen, P. H. (1989). The dopamine uptake inhibitor GBR 12909: selectivity and molecular mechanism of action.European Journal of Pharmacology, 166, 493-509.

Andersen, P. H. (1989). The dopamine uptake inhibitor GBR 12909: selectivity and molecular mechanism of action. European journal of pharmacology, 166(3), 493-504

Castells, X., Casas, M., Pérez- Mañá, C., Roncero, C., Vidal, X., \& Capella, D. (2010). Efficacy of psychostimulant drugs for cocaine dependence. Cochrane Database of Systematic Reviews, (2).

Fensbo, C., Montgomery, S. A., Andersen, J., Hallstrom, C., Schonbeck, G., Zwaan, M., M0oler Nielsen, E. M., Olafsson, K., Ingwersen, S. H. \& Skrumsager, B. K. (1990). GBR 12909: A dose response relationship of the selective dopamine uptake inhibitor in major depression. XVIIth Congress of Collegium Internationale Neuro-Psychopharmacologicum, Kyoto. Abstract 0-11-9-3.
Glowa, J.R., Wojnicki, F.H.E., Matecka, D., Rice, K.C., Rothman, R.B. (1995b) Effects of dopamine reuptake inhibitors on food and cocaine maintained responding II: comparison with other drugs and repeated administration .Experimental and Clinical Psychopharmacology 3:232-239.

Hanzlick, R., Gowitt, G.T., (1991). Cocaine metabolite detection in homicide victims. The Journal of the American Medical Association 265:760-761.

Holman, R.B. (1994). Biological effects of central nervous system stimulants. Addiction, 89(11), 1435-1441.

Hyman, S.E. (1996) Addiction to cocaine and amphetamine. Neuron, 16(5), 901-904.

Kalivas, P.W.; Duffy, P. (1990) Effect of acute and daily cocaine treatment on extracellular dopamine in the nucleus accumbens. Synapse, 5(1), 48-58. 
Koob, G.F. Nestler, E.J. (1997). The neurobiology of drug addiction. The Journal of Neuropsychiatry and Clinical Neurosciences, 9(3), 482-497.

Luoh, H.F. Kuo, T.B. Chan, S.H. Pan, W.H. (1994). Power spectral analysis of electroencephalographic desynchronization induced by cocaine in rats: correlation with microdialysis evaluation of dopaminergic neurotransmission at the medial prefrontal cortex. Synapse, 16(1), 29-35.

Matsumoto, N., Khrestian, C. M., Ryu, K., Lacerda, A. E., Brown, A. M., \& Waldo, A. L. (2010). Vanoxerine, a new drug for terminating atrial fibrillation and flutter. Journal of cardiovascular electrophysiology, 21(3), 311-319.
Rothman, R.B., Mele, A., Reid, A.A., Akunne, H.C., Greig, N., Thurkauf, A. (1991). GBR 12909 antagonizes the ability of cocaine to elevate extracellular levels of dopamine. Pharmacology Biochemistry and Behavior, 40:387-397.

Volkow, N.D., Wang, G.J., Fowler, J.S., Logan, J., Gatley, S.J., Wong, C. (1999). Reinforcing effects of psychostimulants in humans areassociated with increases in brain dopamine and occupancyof D2 receptors.Journal of Pharmacology and Experimental Therapeutics 291:409-415.

Volkow, N. D., Wang, G. J., Fowler, J. S., Logan, J., Franceschi, D., Maynard, L., ... \& Swanson, J. M. (2002). Relationship between blockade of dopamine transporters by oral methylphenidate and the increases in extracellular dopamine: therapeutic implications. Synapse, 43(3), 181-187. 